\title{
EVALUATION OF RIGHT VENTRICLE SYSTOLIC AND DIASTOLIC FUNCTION IN PATIENTS WITH PAROXYSMAL ATRIAL FIBRILLATION
}

\author{
Cuglan Bilal, ${ }^{1}$ Ermis Necip, ${ }^{2}$ Yetkin Ertan, ${ }^{3}$ Karakas Yasin, ${ }^{4}$ \\ Kurtoglu Ertugrul, ${ }^{4}$ Ozdemir Ramazan ${ }^{5}$ \\ ${ }^{1}$ Department of Cardiology, School of Medicine, The University of Beykent, Istanbul, Turkey \\ ${ }^{2}$ Department of Cardiology, School of Medicine, The University of Inonu, Malatya, Turkey \\ ${ }^{3}$ Department of Cardiology, School of Medicine, The University of Istinye, Istanbul, Turkey \\ ${ }^{4}$ Department of Cardiology, Malatya Training and Research Hospital, Malatya, Turkey \\ ${ }^{5}$ Bezmi Alem University, Faculty of Medicine, Department of Cardiology, Istanbul, Turkey
}

Primljen/Received 03. 05. 2020. god.

Abstract: Objective: Atrial fibrillation (AF) is frequently an electrical sign of underlying structural heart disease. Structural remodelling may begin not only in ventricles but also in atrium secondary to AF. In this study, we sought to investigate the effect of paroxysmal atrial fibrillation (PAF) on right ventricle function.

Method: We prospectively analyzed 30 patients diagnosed with PAF and 25 control individuals. Cardiac risk factors and medical treatment of patients were obtained and recorded in both groups. Right ventricle tricuspid annular plane systolic excursion (TAPSE) and Tei indexes were measured as an indicator of right ventricular function.

Results: There was no statistical difference between groups in terms of demographic and clinical characteristics. Tei index was higher and TAPSE was lower in PAF group compared to control individuals ( $p>$ $0.05)$. There was no statistically significant difference between PAF and control groups in terms of right ventricular diastolic functions neither. Although isovolumic relaxation time (IVRT) was higher in PAF group, it did not give statistical significance.

Conclusion: In this study, even not being statistically significant Tei index, which assess right ventricular function was over upper limit in PAF patients. This may have been as the result of prolonged IVRT. This result may indicate that right ventricular diastolic functions may be effected in patients with PAF.

Key words: Atrial Fibrillation, Right Ventricle, 2D Echocardiography.
Prihvaćen/Accepted 20. 06. 2020. god.

\section{INTRODUCTION}

Atrial fibrillation (AF), is the most prevalant type of sustained arrhythmic disease in clinical practice and one of the main cause of hospitalization associated with morbidity and mortality. Epidemiological studies have shown that the most common cause of AF is ischemic heart disease $(1,2)$. Framingham Heart Study has revealead that; left ventricular (LV) wall thickness increasing, LV systolic functions decreasing and increased left atrial (LA) dimensions are independent risk factors for the development of AF (3). Proliferation of myoblasts to fibroblasts in atrium resulting with fibrosis are the major histopathological changes in atrial tissue of patients with AF. This structural remodeling causes electrical decomposition within local conduction, resulting in retention of small re-entry rings. Due to these changes, especially in persistent $\mathrm{AF}$, the absence of atrial contractions leads to increased atrial volume and pressure. Hemodynamic effects such as increased heart rate in atrial fibrillation, absence of atrial contraction and impaired simultaneous contraction of the atria and ventricles may result into ventricular dysfunction that eventually causes symptoms of heart failure $(4,5)$. Paroxysmal atrial fibrillation (PAF), which is described as usually self-terminating AF within 48 hours has intermittant clinical manifestation. Spontaneous conversion rate is low after $48 \mathrm{~h}$ time point that is deadline for electrical or medical cardioversion to prevent embolic complications. After that, rate control strategy and anticoagulant treatment must be considered (6). Right heart is difficult to evaluate by echocardiography 
because of its complexity of anatomical structure. Quantitative evaluation of right ventricular dimensions and functions has been proven to have significant clinical value in both cardiac and pulmonary diseases. Right ventricular functions may be impaired by volume overload, pressure overload and myocardial dysfunction. Diastolic functions tend to deteriorate earlier than sistolic functions unless severe volume overload occurs. As the right ventricular volume increases, the cardiac myofibrils become stretched leading into decrease in right ventricular functions. The right ventricular chambers begin to enlarge resulting into abnormal septal movements. Right atrial (RA) pressure increases and peripheral right heart failure signs appear due to volume overload.

There are several studies evaluating the functions of LA in AF patients $(3,7,8)$. In patients with valvular disease and LA diameter $>40 \mathrm{~mm}$, the incidence of AF increases. The rate of increase in LA diameter was significantly correlated with the transition from normal sinus rhythm to PAF and PAF to chronic AF (9). However, there are few studies assessing the on RA and RV global functions in patients with $\mathrm{AF}(10,11)$. Houltz et al. found that RA size might be an important paratemer in maintaining normal heart rhythm after intraoperative ablation for AF (10). In this study, we aimed to evaluate right ventricular functions by echocardiography in patients with PAF.

\section{PATIENTS AND METHODS}

\section{Patient selection}

Forty-one consecutive patients with PAF who were admitted to Cardiology outpatient clinic were included to the study at Inonu University Faculty of Medicine Turgut Ozal Medical Center between July 2011 to December 2011 and referred to Echocardiography Laboratory for transthoracic echocardiography. Patients who were included in the study were examined for baseline demographic and clinical parameters such as coronary artery disease, cardiovascular risk factors, other diseases, medications, body weight, height and recorded on a study chart. PAF was described as according to the guideline of HRS/EHRA/ECAS. AF was defined as an arrhythmia to be recorded by a 12-lead ECG that has irregularly irregular episode, and lasts sufficiently long or at least 30 seconds on a rhythm strip. PAF was defined as two or more episodes of symptomatic AF recurrency within the preceding 6 months that was not longer than 7 days (6). The patients were selected by; a) results of 24-hour rhythm holter (at least two episodes of PAF) b) two or more PAF episodes detected by emergency department c) during the routine follow up of patients with PAF in outpatient clinic. The exclusion criterias were previous ablation for $\mathrm{AF}$, a left diameter of more than $45 \mathrm{~mm}$, left ventricular ejection fraction of less than $50 \%$, moderate-to-severe mitral valve disease, an age of more than 65 years and secondary atrial fibrillation (hyperthyroidism, infection, postoperative AF). Control group consisted of 25 patients who were admitted to cardiology outpatient clinic with other cardiac symptoms without AF or other rhythm disorders. These individuals had similar baseline characterictics with PAF group such as age, sex and medical history. This trial was approved by the local ethic committee. Written informative acceptance was obtained from all patients regarding their participation in our study. Eleven patients were excluded due to having pulmonary embolism, hyperthyroidism, postoperative AF, moderate to severe valvular disease in the study.

\section{Transthoracic Echocardiography}

Transthoracic echocardiography was performed in all patients. Conventional echocardiographic parameters of left and right ventricles were measured according to the recommendations of the American Society of Echocardiography (12). Briefly, RV dimensions were calculated from right ventricle apical 4-chamber view at end-diastole. And after this measurement, diameter $>42 \mathrm{~mm}$ at the base and $>35 \mathrm{~mm}$ at the mid level was defined as RV dilatation. Also, RA dimensions were calculated from the apical 4-chamber at the same frame. RA length (the main dimension) $>53 \mathrm{~mm}, \mathrm{RA}$ diameter $>44 \mathrm{~mm}$ and RA area $>18 \mathrm{~cm} 2$, at end diastole was defined as RA enlargement. Systolic functions of the right ventricle were evaluated by right ventricular ejection fraction (EF), tricuspid annular plane sistolic excursion (TAPSE), isovolemic acceleration and myocardial performance index (MPI). The MPI (Tei index) measured by isovolumic contraction time (IVCT), isovolemic relaxation time (IVRT), and ejection time (ET), was calculated with IVRT + IVCT) / ET formulation. Tei index $>0.55$ measured by tissue doppler imaging indicates RV dysfunction (11). TAPSE is defined as to calculate the distance of systolic excursion of the RV annular segment along its longitudinal plane, from a standart four chamber window. It is measured from the tricuspid lateral annulus. TAPSE $<16 \mathrm{~mm}$ assumes RV systolic dysfunction. Myocardial acceleration during isovolumic contraction (IVA) is defined as the peak isovolumic myocardial velocity divided by time to peak velocity. Diastolic functions of the right ventricle were evaluated by Doppler velocities of the transtricuspid flow such as (E, A, and E/A), and tissue Doppler velocities of the tricuspid annulus (E /A ), and IVRT from the apical 4-chamber view.

The diameters of left ventricle were measured from long-axis of parasternal view at the end of 
diastole and systole. Left atrium diameter was measured from parasternal long-axis view. Systolic and diastolic functions of the left ventricle were evaluated by EF, MPI, IVA, tissue doppler of mitral valve parameters $(\mathrm{E}, \mathrm{A}, \mathrm{St})$ and deceleration time which are measured from the 4-chamber apical view.

\section{Statistical Analysis}

All statistical analyses were performed using SPSS version 15.0 (SPSS, Inc., Chicago, Illinois) for windows software. Continuous variables were expressed as mean value \pm standard deviation for parametric variables. Categorical variables were defined as counts and percentages and compared the groups using Fisher's exact chi-square test and Pearson's chi square test. The
Kolmogorov-Smirnov test was used for the assessment of normality and differences between the means were compared by unpaired t-test. $\mathrm{P}$ value $<0.05$ was considered as statistically significant in every test.

\section{RESULTS}

Our study included 55 patients (30 patients diagnosed with PAF and 25 patients were taken as a control group). The mean age was $52.0 \pm 6.2$ years in the patient group and $48.1 \pm 6.5$ years in control group. All baseline skills such as clinical, demographic characteristics, and pathologies of the study population are presented in Table 1 . And there were no statistically difference in respect to age, smoking, gender, diabetes mellitus, hypertension, coronary artery disease, and hyperli-

Table 1. Baseline characteristics of patients and control groups

\begin{tabular}{|c|c|c|c|c|}
\hline Characteristics & \multicolumn{2}{|c|}{ Patient $(\mathrm{n}=30)$} & Control $(n=25)$ & P value \\
\hline Age & \multicolumn{2}{|c|}{$52.0 \pm 6.2$} & $48.1 \pm 6.5$ & NS \\
\hline \multirow{2}{*}{ Gender } & Women & $12(\% 40)$ & $10(\% 40)$ & \multirow{2}{*}{ NS } \\
\hline & Men & $18(\% 60)$ & $15(\% 60)$ & \\
\hline Diabetes Mellitus & \multicolumn{2}{|c|}{$7(\% 23.3)$} & $4(\% 16)$ & NS \\
\hline Hypertension & \multicolumn{2}{|c|}{$10(\% 33.3)$} & $7(\% 28)$ & NS \\
\hline Obesity & \multicolumn{2}{|c|}{$6(\% 20)$} & $1(\% 4)$ & NS \\
\hline Smoking & \multicolumn{2}{|c|}{$13(\% 43.3)$} & $9(\% 36)$ & NS \\
\hline BMI, $\mathrm{kg} / \mathrm{m}^{2}$ & \multicolumn{2}{|c|}{$27.0 \pm 3.7$} & $26.4 \pm 2.5$ & NS \\
\hline Hyperlipidemia & \multicolumn{2}{|c|}{$9(\% 30)$} & $8(\% 32)$ & NS \\
\hline SVE & \multicolumn{2}{|c|}{$1(\% 3.3)$} & $0(0)$ & NS \\
\hline Valvulardisease & \multicolumn{2}{|c|}{$11(\% 36.7)$} & $10(\% 40)$ & NS \\
\hline
\end{tabular}

BMI: Body mass index, CVE: cerebrovascular event.

Table 2. Left ventricle echocardiografic results (mean)

\begin{tabular}{|l|c|c|c|}
\hline & Patients $(\mathbf{n}=\mathbf{3 0})$ & Control $(\mathbf{n}=\mathbf{2 5})$ & P value \\
\hline LA $(\mathrm{cm})$ & $3.6 \pm 0.5$ & $3.5 \pm 0.4$ & NS \\
\hline LVEDd $(\mathrm{cm})$ & $4.6 \pm 0.4$ & $4.6 \pm 0.3$ & NS \\
\hline LVESd $(\mathrm{cm})$ & $3.0 \pm 0.3$ & $3.2 \pm 0.4$ & $\mathbf{0 . 0 4 8}$ \\
\hline EF $(\%)$ & $60.1 \pm 4.3$ & $60.6 \pm 3.0$ & NS \\
\hline IVS $(\mathrm{cm})$ & $1.1 \pm 0.1$ & $1.0 \pm 0.1$ & NS \\
\hline PW $(\mathrm{cm})$ & $1.0 \pm 0.1$ & $1.0 \pm 0.1$ & NS \\
\hline E & $73.3 \pm 19.0$ & $67.4 \pm 15.1$ & $\mathbf{0 . 0 4 2}$ \\
\hline A & $79.3 \pm 21.8$ & $68.4 \pm 11.5$ & NS \\
\hline Dt & $210.8 \pm 64.3$ & $194.2 \pm 47.0$ & NS \\
\hline St & $10.5 \pm 2.3$ & $12.0 \pm 2.5$ & NS \\
\hline Et/At & $1.0 \pm 0.5$ & $1.1 \pm 0.5$ & NS \\
\hline E/E' & $7.2 \pm 3.6$ & $5.9 \pm 2.2$ & NS \\
\hline MPI & $0.5 \pm 0.1$ & $0.5 \pm 0.1$ & . \\
\hline IVA & $2.3 \pm 0.5$ & $2.4 \pm 0.7$ & \\
\hline
\end{tabular}

LA: left atrium, LVEDd: left ventricular end diastole diameter, LVESd: left ventricular endsystolic diameter, IVS: interventricular septum, PW: posterior wall, EF: ejection fraction, E: early rapid filling, A: late filling after atrial contraction, Dt: deceleration time, MPI: myocardial performance index, IVA: Isovolumic acceleration, Dp/dt: rate of pressurerise in the ventricles. 
Table 3. Right ventricle echocardiografic results (mean)

\begin{tabular}{|l|c|c|c|}
\hline & Patients $(\mathbf{n}=\mathbf{3 0})$ & Control $(\mathbf{n}=\mathbf{2 5})$ & Pvalue \\
\hline RA $(\mathrm{cm})$ & $4.0 \pm 05$ & $3.9 \pm 0.4$ & NS \\
\hline RA area $\left(\mathrm{cm}^{2}\right)$ & $16.6 \pm 4.3$ & $15.6 \pm 2.7$ & NS \\
\hline RV $(\mathrm{cm})$ & $3.9 \pm 0.5$ & $4.0 \pm 0.3$ & NS \\
\hline FAD & $43.1 \pm 10.4$ & $44.0 \pm 9.3$ & NS \\
\hline E & $50.1 \pm 10.0$ & $51.7 \pm 12.2$ & NS \\
\hline $\mathrm{A}$ & $51.4 \pm 13.8$ & $52.2 \pm 13.2$ & NS \\
\hline Dt & $233.0 \pm 63.0$ & $240.0 \pm 62.0$ & NS \\
\hline St & $12.6 \pm 3.1$ & $14.1 \pm 3.0$ & NS \\
\hline Et/At & $0.8 \pm 0.4$ & $0.9 \pm 0.4$ & NS \\
\hline E/E' & $5.0 \pm 1.5$ & $4.6 \pm 1.5$ & NS \\
\hline MPI & $\mathbf{0 . 6} \pm \mathbf{0 . 1}$ & $0.5 \pm 0.1$ & NS \\
\hline IVA & $2.6 \pm 1.1$ & $2.6 \pm 1.0$ & NS \\
\hline TAPSE & $1.9 \pm 0.4$ & $2.0 \pm 0.2$ & NS \\
\hline sPAP & 31.50 & 29.46 & (65.0 \\
\hline IVRT & $\mathbf{8 5 . 0} \pm 14.5$ & & . \\
\hline
\end{tabular}

RA: Right atrium, RV: Right ventricle, MPI:myocardial performance index, TAPSE: Tricuspid annular plane systolic excursion, IVA: Isovolumic acceleration, IVRT: isovolumic relaxation time, sPAP: sistolic pulmonary artery pressure.

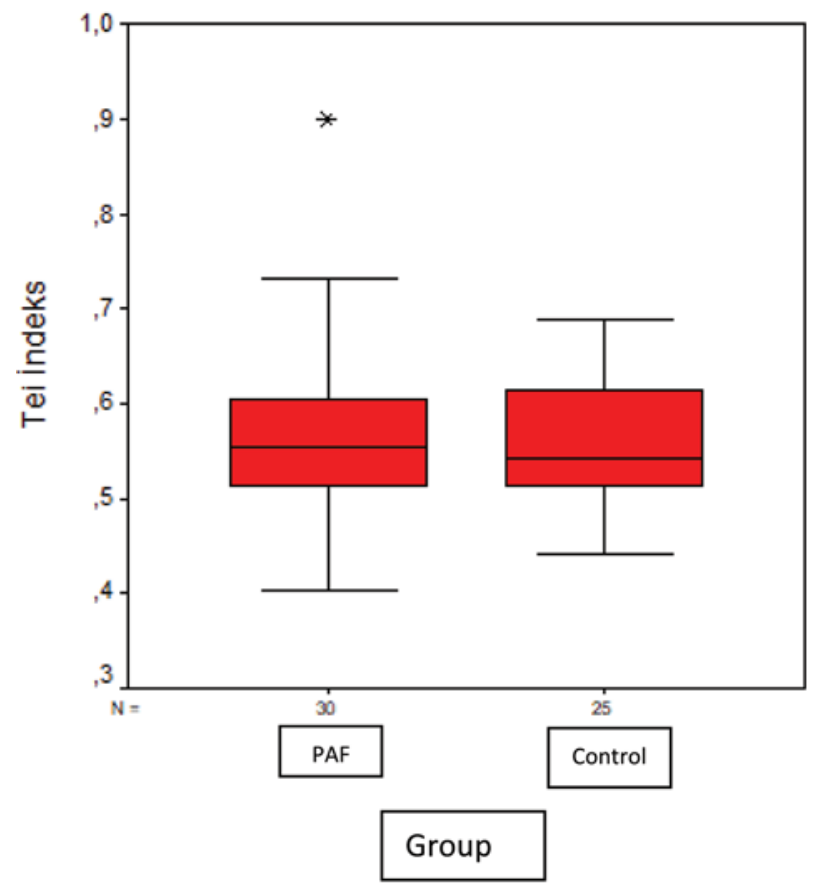

Figure 1. Comparising of right ventricle Tei index in patients with PAF and controls

pidemia between the groups. In addition, there was no difference in terms of mild regurgitation of mitral, aortic and tricuspid valves when the groups compared. All parameters of LV and RV such as systolic and diastolic functions are summarized in Table 2 and Table 3, respectively. There was no statistically significant difference in terms of RV systolic and diastolic functions between the groups. In the PAF group, the Tei index was higher than the upper limit of the reference values. This was as a result of prolongation of IVRT (Figure 1).

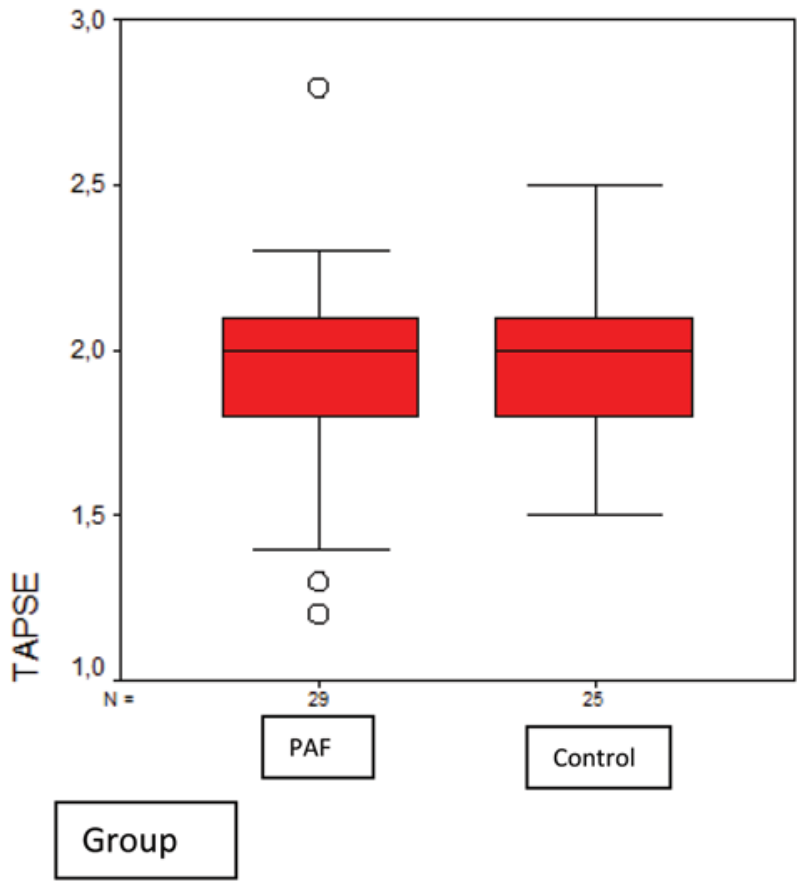

Figure 2. Comparising of right ventricle TAPSE in patients with $P A F$ and controls

TAPSE was $1.9 \pm 0.4$ in the PAF group and $2.0 \pm 0.2$ in the control group $(\mathrm{p}=0.55)$ (Figure 2). Also, RA dimension was higher in PAF group.

\section{DISCUSSION}

In this study, we could not found any statistically significant changing in right ventricular functions in patients with PAF though some parameters were higher in PAF group than the control group such as RA diame- 
ter which might be an independent risk factor for the development of AF. As a consequent of these results, it can be speculated that intermittant occurence of atrial fibrillation may not cause any functional disturbances on right ventricle during the $\mathrm{AF}$ free period. But, there were a few differences in PAF group that did not reach the statistically significance such as RA diameter and Tei index. We found that the RA diameter was higher in the PAF group but it was not reached to statistically significane between the groups. Also there was a decreased right ventricular systolic functions in PAF group, despite of being no statistical significant difference between the groups in terms of TAPSE and pulse tissue doppler St. In the current guidelines, the upper limit for Tei index measured by tissue doppler is 0.55 (13). In our study, the Tei index value in PAF group was found to be increased. This implays that; there might be a right ventricular dysfunction in the PAF group when evaluated with Tei index. Assessment of these data concluded that this elevation was due to the elongation of the right ventricular IVRT. Elongation in IVRT may reflect prolonged diastolic filling time, increased right ventricular end-diastolic pressure, or myocardial relaxation defect.

PAF could be an early sign of diastolic dysfunction of RV. In a similar study performed by Eidem et al. (14) found that; although right ventricular functions were normal in patients with right ventricular volume overload as the result of atrial septal defect, Tei index was higher than in normal individuals due to prolongation of IVRT. In addition, it was found that right ventricular dysfunction could be detected subclinically with Tei index as this was correlated with cardiac involvement in patients with chronic obstructive pulmonary disease. Moreover in this study, prolongation of IVRT was associated with the severity of the disease and therefore subclinically both systolic and diastolic dysfunction may occur in these patients (15). It has been found that Tei index had prognostic value in pulmonary hypertension and changing in Tei index could affect the clinical status of these patients $(16,17)$. Field et al. (18) found that right ventricular dysfunction detected by Tei index is a predictive factor for mortality, transplantation and left ventricular assist device use. In our study, these changes may occur as a result of atrial changes in PAF patients or it may occur as a result of changes in the ventricle together with ventricular response due to rapid and non-rhythmic ventricular stimulation during PAF episodes.

The risk of developing AF in patients with a history of valve disease is increased 1.8 times in men and 3.4 times in women (19). Similarly, a sustained hypertension and an increased pulse pressure are associated with an increased risk of AF (20). Due to these stress factors, the occurence of ventricular hypertrophy and atrial dilatation play an important role in the pathogenesis of AF. These subclinical changes develop to adapt changes initially induced by increased afterload or preload. These changes gradually leads to the decrease in ventricular and atrial functions. The relationship between atrial dilatation and AF is well known and well documented. Acar et al. (21) founded that increased in RA diameter could be an independent risk factor for the development of AF in patients on hemodialysis. Conversely, it might be speculated that this increasing in RA diameter could be a result of PAF even not reached to statistically significance in our study. Relevantly, in our study, the changes in right ventricular systolic and diastolic parameters were higher in the patients with PAF patients compared to the control group despite of being not statistically significant.

In PAF group patients, there were no statistical significant differences when left heart parameters were evaluated in accordance with current guidelines. However, we have found that there was statistically significance difference in st value. This might be resulted with left ventricular systolic and diastolic dysfunction in patients with PAF in a long time.

\section{Limitations in our study}

There are several limitations in the current study that should be addressed. Firstly, our study included limited number of patients. Another important limitation of the present study was the lack of datas on duration PAF and numbers of PAF episodes untill study participation. Lastly, intra-interobserver variability related to the parameters measured in echocardiography was not performed. Therefore, our findings may not be applicable to the entire PAF population. Therefore, large scaled and mutlicentered studies are needed.

\section{CONCLUSION}

In this study, we could not find any statistically significant changing in right ventricular functions in patients with PAF. But, there were a few differences in PAF group that did not reach the statistically significance such as RA diameter and Tei index. Tei index was detected over the normal references value because of delaying in IVRT. This result may indicate that right ventricular diastolic functions could be affected in patients with PAF. Moreover, increasing in RA diameter might be assumed that it could be a result of PAF in this patients. These results need to be supported by future studies including more patients.
Abbreviations
$\mathbf{A F}$ - Atrial fibrillation
PAF - paroxysmal atrial fibrillation
TAPSE - tricuspid annular plane systolic excursion 
IVRT - isovolumic relaxation time

EF - ejection fraction

MPI - myocardial performance index

Conflict of Interests: The authors declare that there are no conflicts of interest related to this article.
Funding: None

\section{Licensing}

This work is licensed under a Creative Commons Attribution 4.0 International (CC BY 4.0) License.

\title{
Sažetak
}

\section{PROCENA SISTOLNE I DIJASTOLNE FUNKCIJE DESNE KOMORE KOD PACIJENATA SA PAROKSIZMALNOM ATRIJALNOM FIBRILACIJOM}

\author{
Cuglan Bilal, ${ }^{1}$ Ermis Necip, ${ }^{2}$ Yetkin Ertan, ${ }^{3}$ Karakas Yasin, \\ Kurtoglu Ertugrul, ${ }^{4}$ Ozdemir Ramazan \\ Department of Cardiology, School of Medicine, The University of Beykent, Istanbul, Turkey \\ ${ }^{2}$ Department of Cardiology, School of Medicine, The University of Inonu, Malatya, Turkey \\ ${ }^{3}$ Department of Cardiology, School of Medicine, The University of Istinye, Istanbul, Turkey \\ ${ }^{4}$ Department of Cardiology, Malatya Training and Research Hospital, Malatya, Turkey \\ ${ }^{5}$ Bezmi Alem University, Faculty of Medicine, Department of Cardiology, Istanbul, Turkey
}

Uvod: Atrijalna fibrilacija (AF) je često električni znak postojeće strukturne bolesti srca. Strukturno remodeliranje sekundarno može početi ne samo u komorama već i u pretkomorama zbog AF. U ovoj studiji, pokušali smo da istražimo efekat paroksizmalne atrijalne fibrilacije (PAF) na funkciju desne komore.

Metod: Prospektivno smo analizirali 30 pacijenata kod kojih je dijagnostikovana PAF i 25 u kontrolnoj grupi. Srčani faktori rizika i lečenje obe grupe pacijenata su dobijeni i sačuvani. Procena funkcije desne komore izvedena je pomocu parametara TAPSE i Tei indeksa.

Rezultati: Nije bilo statistički značajne razlike između grupa u smislu demografskih i kliničkih karakteristika.Tei indeks je bio viši, a TAPSE niži u PAF grupi

\section{REFERENCES}

1. Zoni-Berisso M, Lercari F, Carazza T, Domenicucci S Epidemiology of atrial fibrillation: European perspective. Clin Epidemiol. 2014; 6: 213-20.

2. Wilke T, Groth A, Mueller S, Pfannkuche M, Verheyen F, Linder R, et al. Incidence and prevalence of atrial fibrillation: an analysis based on 8.3 million patients. Europace. 2013; 15(4): 486-93.

3. Vaziri SM, Larson MG, Benjamin EJ, Levy D. Echocardiographic predictors of nonrheumatic atrial fibrillation. The Framingham Heart Study. Circulation. 1994; 89(2): 724-30.

4. Denham NC, Pearman CM, Caldwell JL, Madders GW, Eisner DA, Trafford AW, et al. Calcium in the pathophysiology of atrial fibrillation and heart failure. Front Physiol. 2018; 9: 1380.

5. Prabhu S, Voskoboinik A, Kaye DM, Kistler PM. Atrial fibrillation and heart failure - cause or effect? Heart Lung Circ. 2017; 26(9): 967-74.

6. Calkins H, Hindricks G, Cappato R, Kim YH, Saad EB, Aguinaga L, et al. 2017 HRS/EHRA/ECAS/APHRS/SOLAECE expert consensus statement on catheter and surgical ablation of atrial fibrillation. Europace. 2018; 20(1): e1-e160. u poređenju sa kontrolnom grupom ( $p>0,05)$. Nije nađena statistički značajna razlika između PAF i kontrolne grupe u pogledu dijastolne funkcije desne komore. Iako je vreme izovolemijske relaksacije (IVRT) bilo veće u PAF grupi, to nije dalo statistički značaj.

Zaključak: U ovoj studiji, iako nije od statističkog značaja, Tei indeks kojim se procenjuje funkcija desne komore bio je iznad gornje granice u PAF grupi. To je moglo biti rezultat produženog IVRT-a. Ovaj rezultat može ukazivati da dijastolna funkcija desne komore može biti izmenjena kod pacijenata sa paroksizmalnom atrijalnom fibrilacijom.

Ključne reči: atrijalna fibrilacija, desna komora, 2D elektrokardiografija.

7. Floria M, Blommaert D, Lacrosse M, Ambarus V, Dormal F, Dabiri Abkenari L, et al. Assessment of left atrial shape and volume in structural remodeling secondary to atrial fibrillation. Journal of interventional cardiac electrophysiology : an international journal of arrhythmias and pacing. 2009; 25(3): 167-70.

8. Sarvari SI, Haugaa KH, Stokke TM, Ansari HZ, Leren IS, Hegbom F, et al. Strain echocardiographic assessment of left atrial function predicts recurrence of atrial fibrillation. Eur Heart J Cardiovasc Imaging. 2016; 17(6): 660-7.

9. Jurin I, Hadzibegovic I, Durlen I, Jaksić Jurinjak S, Misković D, Ajduk M, et al. Left atrium size and red cell distribution width predict atrial fibrillation progression from paroxysmal or persistent to permanent. Acta Clinica Belgica. 2020; 75(3): 205-11.

10. Houltz B, Johansson B, Berglin E, Karlsson T, Edvardsson N, Wandt B. Left ventricular diastolic function and right atrial size are important rhythm outcome predictors after intraoperative ablation for atrial fibrillation. Echocardiography. 2010; 27(8): 961-8

11. Donal E, Lip GY, Galderisi M, Goette A, Shah D, Marwan M, et al. EACVI/EHRA Expert Consensus Document on 
the role of multi-modality imaging for the evaluation of patients with atrial fibrillation. Eur Heart J Cardiovasc Imaging. 2016; 17(4): 355-83.

12. Lang RM, Badano LP, Mor-Avi V, Afilalo J, Armstrong A, Ernande L, et al. Recommendations for cardiac chamber quantification by echocardiography in adults: an update from the American Society of Echocardiography and the European Association of Cardiovascular Imaging. J Am Soc Echocardiogr. 2015; 28(1): 1-39.e14.

13. Rudski LG, Lai WW, Afilalo J, Hua L, Handschumacher MD, Chandrasekaran K, et al. Guidelines for the echocardiographic assessment of the right heart in adults: a report from the American Society of Echocardiography endorsed by the European Association of Echocardiography, a registered branch of the European Society of Cardiology, and the Canadian Society of Echocardiography. J Am Soc Echocardiogr. 2010; 23(7): 685-713.

14. Eidem BW, O’Leary PW, Tei C, Seward JB. Usefulness of the myocardial performance index for assessing right ventricular function in congenital heart disease. Am J Cardiol. 2000; 86(6): 654-8.

15. Ozben B, Basaran Y. [Echocardiography and other imaging modalities in pulmonary arterial hypertension]. Anadolu Kardiyol Derg. 2010; 0 (Suppl 1): 27-35.
16. Yücel M, Alp H, Yorulmaz A, Karaarslan S, Baysal T. Prediction of the development of pulmonary arterial hypertension with Tei Index in congenital heart diseases with left-to-right shunt. Turk Kardiyol Dern Ars. 2019; 47(6): 466-75.

17. Giusca S, Popa E, Amzulescu MS, Ghiorghiu I, Coman IM, Popescu BA, et al. Is right ventricular remodeling in pulmonary hypertension dependent on etiology? An echocardiographic study. Echocardiography. 2016; 33(4): 546-54.

18. Field ME, Solomon SD, Lewis EF, Kramer DB, Baughman KL, Stevenson LW, et al. Right ventricular dysfunction and adverse outcome in patients with advanced heart failure. $\mathrm{J}$ Card Fail. 2006; 12(8): 616-20.

19. Kavousi M. Differences in epidemiology and risk factors for atrial fibrillation between women and men. Front Cardiovasc Med. 2020; 7:3.

20. O'Neal WT, Soliman EZ, Qureshi W, Alonso A, Heckbert SR, Herrington D. Sustained pre-hypertensive blood pressure and incident atrial fibrillation: the Multi-Ethnic Study of Atherosclerosis. J Am Soc Hypertens. 2015; 9(3): 191-6.

21. Acar G, Akcay A, Dogan E, Isik IO, Sokmen A, Sokmen $\mathrm{G}$, et al. The prevalence and predictors of atrial fibrillation in hemodialysis patients. Turk Kardiyol Dern Ars. 2010; 38(1): 8-13.

\author{
Correspondence to/Autor za korespondenciju \\ Bilal Cuglan, MD \\ Department of Cardiology, School of Medicine, The University of Beykent \\ Cumhuriyet Mah. Buyukcekmece / Istanbul, Turkey. \\ Email: bilalcuglan@hotmail.com
}

